\title{
Toksisitas Isolat Lokal Bacillus thuringiensis (H-14) dan Isolat Sandi 18 Serta Lama Efektivitasnya di dalam Air terhadap Larva Nyamuk Anopheles dan Culex
}

\author{
DANIEL LANTANG* DAN ROSYE H.R. TANJUNG \\ ${ }^{1}$ Jurusan Biologi FMIPA Universitas Cenderawasih, Jayapura-Papua \\ Diterima: tanggal 18 Februari 2010 - Disetujui: 28 Maret 2010 \\ (C) 2010 Jurusan Biologi FMIPA Universitas Cenderawasih
}

\begin{abstract}
The research of toxicity local isolate Bacillus thurigiensis $(\mathrm{H}-14)$ and 18 codeword isolate along the efectivity on the water concerning to the Culex and Anopheles. The research aim to acquainted about the toxicity of $B$. thuringiensis isolate H-14 local and 18 codeword isolate along of the toxicity on the water concerning to the Culex and Anopheles. The methode is laboratory experiment wich used complete randome, analysis the data to wich BNJ test and $0.05 \%$ confidence standart. The result shows that isolate of local B. huringiensis $\mathrm{H}-14$ and coderword 18 toxic concerning to Culex and Anopheles B.thurngiensis H-14 $0.06 \mathrm{ml}$ concentrate, $0.08 \mathrm{ml}$ concentrate and 0.1 of effective of the Anopheles death until 6 day, and $0.1 \mathrm{ml}$ effective concentrate show the Culex death until 7 day.Isolate 18 in 0.08 concentrate and 0.1 effective of Culex until 5 day and $0.1 \mathrm{ml}$ concentrate $0.1 \mathrm{ml}$ effective of the Anopheles until 7 day. Analysis varians shows the different act control concentrate in the other side, the act of concentrate isnt different significant.
\end{abstract}

Key words: Bacillus thuringiensis, Local isolate, toxicity, Anopheles and Culex larva.

\section{PENDAHULUAN}

Pengendalian biologi biasanya dilakukan dengan memanfaatkan organisme hidup dalam mengendalikan hama atau vektor penyakit pada tanaman, hewan dan manusia. Organisme yang telah digunakan untuk pengendalian biologi, meliputi virus, jamur dan bakteri (Huffaker \& Messenger, 1989; Hadioetomo \& Rusmana, 1996).

Salah satu organisme yang sedang dikembangkan penggunaannya sebagai pengendali biologis adalah bakteri Bacillus

\footnotetext{
*Alamat Korespondensi:

Laboratorium Biologi FMIPA, Jln. Kamp Wolker, Kampus Baru UNCEN-WAENA, Jayapura Papua. 99358, Telp. (0967) 572116

email: d_lantang@yahoo.co.id
}

thuringiensis. Bakteri B. thuringiensis adalah mikroorganisme yang patogen terhadap insekta dari Ordo Lepidoptera, Coleoptera dan Diptera, selain itu tidak menyebabkan penyakit pada vertebrata termasuk manusia (Anonim, 2004a).

B. thuringiensis adalah bakteri yang terdapat secara alamiah di alam dan dapat dijumpai di berbagai macam habitat, seperti tanah, air dan lumpur. B. thuringiensis merupakan bakteri entomopatogen, maka bakteri ini paling umum digunakan sebagai pelaku biokontrol dalam mengendalikan serangan hama oleh serangga. Bioinsektisida berbahan aktif $\boldsymbol{B} \boldsymbol{t}$ (B. thuringiensis) pertama kali dipublikasikan oleh Berliner pada tahun 1911, sedangkan di Indonesia dikenal sebagai bioinsektisida oleh petani pada tahun 1970-an (Wardhani, 1996; Permatasari, 1998; Oktavina, 1999). 
Nadrawati dkk (1994) menemukan 45 isolat $B$. thuringiensis dari beberapa lokasi di Daerah Istimewa Yogjakarta, dan 4 isolat diantaranya dapat menyebabkan mortalitas lebih dari 50\% pada ulat Litura. Hadioetomo \& Rusmana (1996) yang telah mengisolasi $B$. thuringiensis dari berbagai daerah di Sulawesi Selatan dan Jawa Barat, menemukan isolat dari peternakan ulat sutra di Sulawesi Selatan yang patogenitasnya paling tinggi terhadap larva Crococidolomia binotalis.

Blondine dkk (2000), mengisolasi B. thuringiensis pada habitat tanah di Salatiga dan menemukan 12 isolat, satu isolat diantaranya mempunyai toksisitas yang tinggi terhadap larva nyamuk Aedes aegypti.

Lantang (2005) mengkarakterisasi B. thuringiensis pada beberapa habitat tanah di Papua dan menemukan 41 isolat, dua isolat diantaranya toksik terhadap larva Anopheles farauti Laveran, yaitu isolat B.thuringiensis (H-14) dan isolat $B$. thurngiensis sandi 18 yang belum teridentifikasi secara serologi.

Pengendalian biologis dengan menggunakan berbagai macam biakan $B$. thuringiensis baik berupa biakan murni yang diperoleh dari luar negeri maupun berbagai macam isolat lokal telah banyak dilakukan terhadap berbagai vektor. Nyamuk Anopheles, Aedes, dan Culex merupakan vektor utama penyakit malaria, demam berdarah, dan filariasis di tanah Papua dan pulau-pula di sekitarnya yang hingga saat ini masih merupakan penyebab kematian utama.

Meskipun pemberantasan vektor telah dilakukan dengan berbagai cara, misalnya pembersihan sarang nyamuk (PSN) dan penggunaan berbagai macam jenis pestisida, tetapi belum dapat menurunkan insidensi malaria, demam berdarah dan filariasis di Papua. Menurut Munif (1997) dan Novizan (2002), penggunaan pestisida pada dasarnya dapat mematikan vektor dalam waktu yang cepat, tetapi hanya ditujukan terhadap nyamuk dewasa, karena hanya dilakukan di dalam rumah dan di sekitar pekarangan, sedangkan tingkat larvanya tetap hidup. Selain itu penggunaan pestisida secara terus menerus akan menyebabkan terjadinya resistensi terhadap vektor dan dampak terhadap berbagai masalah lingkungan lainnya.

Meskipun isolat lokal B. thuringiensis (H-14), dan isolat $B$. thuringiensis sandi 18 toksik terhadap larva nyamuk Anopheles farauti Laveran, namun masih perlu diketahui toksisitasnya lebih lanjut terhadap semua larva nyamuk Anopheles dan Culex yang diperoleh secara langsung dari lapangan serta lama toksisitasnya dalam air.

\section{METODE PENELITIAN}

\section{Waktu dan Tempat Penelitian}

Penelitian uji toksisitas dilakukan di Laboratorium Mikrobiologi FMIPA Universitas

Cenderawasih Jayapura, mulai dari bulan Juni sampai Oktober 2009. Pengambilan larva nyamuk Anopheles dan Culex dilakukan di Distrik Nimboran (Jayapura) dan Distrik Arso (Keerom).

\section{Metode Penelitian}

Metode yang digunakan dalam penelitian ini untuk mengetahui toksisitas isolat lokal $B$. thuringiensis (H-14) dan isolat sandi 18 adalah eksperimen laboratorium. Isolat yang digunakan dalam penelitian ini adalah isolat lokal $B$. thuringiensis (H-14) dan isolat sandi 18. masingmasing diambil 1ml, dimasukkan kedalam Erlenmeyer yang berisi medium TPB sebanyak 100 $\mathrm{ml}$ selanjutnya diinkubasikan pada Shaker incubator selama 72 jam (Hadioetomo, 1997; Blondine, 2000; Lantang 2005).

Biakan B. thuringiensis pada medium TPB, dengan menggunakan metode menurut Blondine (2000), dan Lantang (2005) masing-masing di pipet sebanyak $0.02 \mathrm{ml} ; 004 \mathrm{ml} ; 0.06 \mathrm{ml}, 0.08 \mathrm{ml}$, dan $0.1 \mathrm{ml}$ selanjutnya diinokulasikan ke dalam mangkok plastik yang telah berisi air sebanyak $200 \mathrm{ml}$ dan 50 larva nyamuk. Setiap perlakuan konsentrasi diulang sebanyak 4 kali, pengamatan kematian larva dilakukan pada hari ke 2 setelah inokulasi. Setelah pengamatan dilakukan, maka semua larva yang terdapat dalam mangkok dikeluarkan dengan pipet, kemudian kedalam mangkok plastik dimasukkan lagi larva sebanyak 50 ekor, perlakuan ini dilakukan sampai dijumpai 
tingkat kematian larva di bawah $50 \%$ guna mengetahui lama toksisitas dalam air (Munif, 1997).

\section{Rancanan Penelitian}

Penelitian ini menggunakan pola rancangan acak lengkap dan jika analisis varians pada taraf kepercayaan 5\% menunjukkan konsentrasi perlakuan berbeda nyata, maka dilakukan uji lanjut dengan menggunakan uji BNJ pada taraf kepercayaan $5 \%$ guna membandingkan toksisitas masing-masing konsentrasi.

\section{HASIL DAN PEMBAHASAN}

Toksisitas isolate lokal $B$. thuringiensis H-14 dan sandi 18 terhadap larva Anopheles dan Culex, serta lama efektifitasnya di dalam air, seperti yang ditunjukkan pada gambar 1, 2, 3, dan 4 .

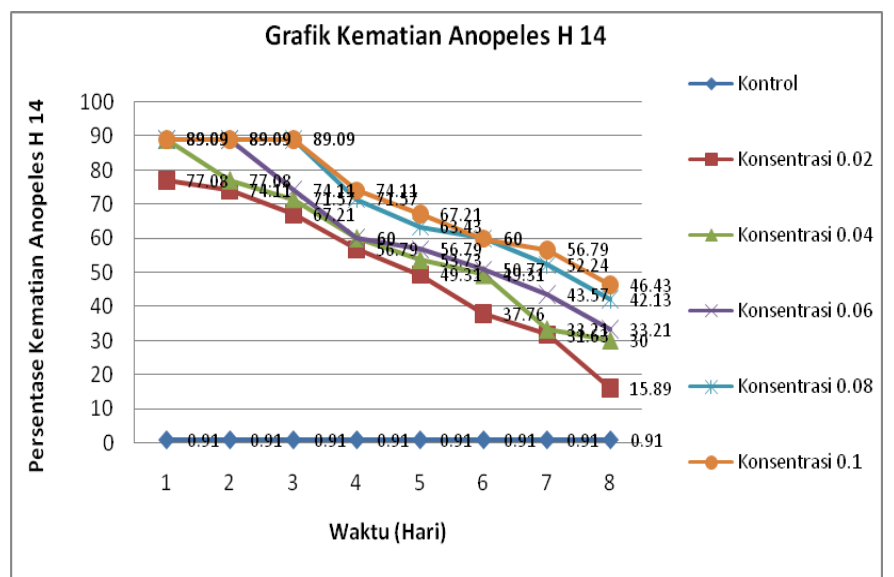

Gambar 1. Grafik kematian Anopeles H 14.

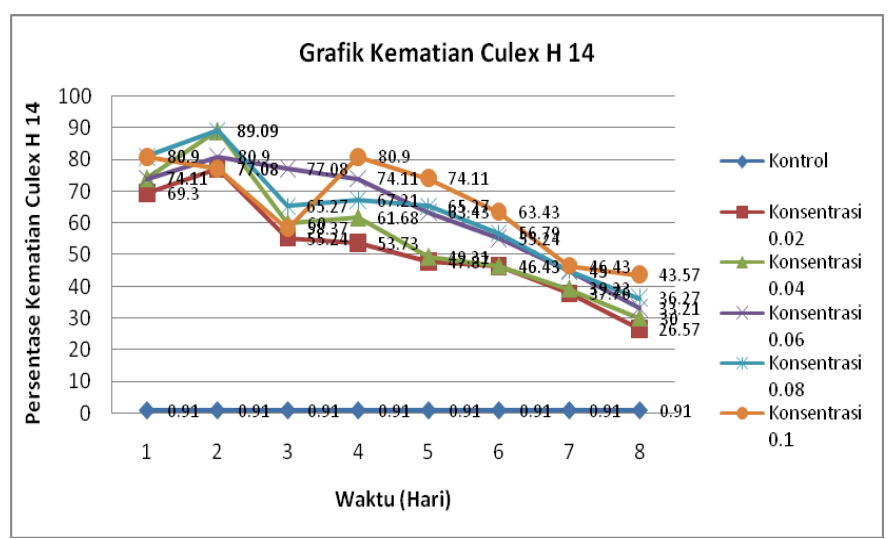

Gambar 2. Grafik kematian Culex H 14.
Gambar 1, toksisitas B. thuringiensis terhadap efektifitas kematian larva Anopheles instar 3 untuk setiap konsentrasi menunjukkan efektifitas terhadap kematian larva untuk konsentrasi 0.02 $\mathrm{ml}$, efektive sampai hari ke 4 yaitu 56. 79\%, sedangkan konsentrasi $0.04 \mathrm{ml}$ efektif sampai hari ke 5 yaitu $53.73 \%$., konsentrasi $0.06 \mathrm{ml}$ efektif sampai hari ke 5 . Sedangkan konsentrasi $0.08 \mathrm{ml}$ dan $0.1 \mathrm{ml}$ efektif sampai hari ke 6, yaitu masingmasing $52.24 \%$ dan $56,79 \%$

Gambar 2. toksisitas B. thuringiensis isolate sandi 18 terhadap efektifitas kematian larva Anopheles untuk setiap konsentrasi, menunjukkan efektifitas untuk konsentrasi $0.02 \mathrm{ml}$ efektif sampai hari ke 4 yaitu $56.79 \%$, konsentrasi $0.04 \mathrm{ml}$ efektif sampai hari ke 5yaitu 50.77\%, sedangkan konsentrasi $0.06 \mathrm{ml}$ dan $0.08 \mathrm{ml}$ efektif sampai hari ke 6 yaitu masing-masing $50.77 \%$ dan $60 \%$, serta konsentrasi $0.1 \mathrm{ml}$ efektif sampai hari ke 7 yaitu efektif $55.24 \%$.

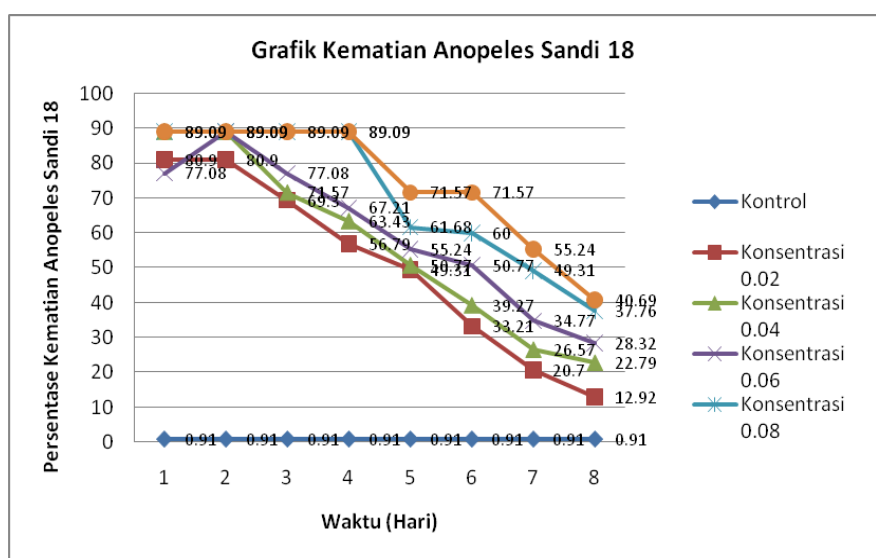

Gambar 3. Grafik kematian Anopeles Sandi 18.

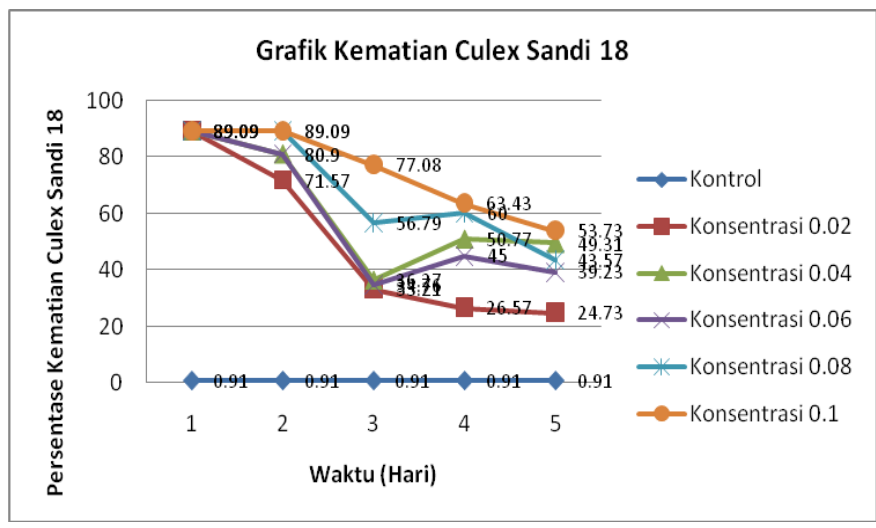

Gambar 4. Grafik kematian Culex Sandi 18. 
Gambar 3, menunjukkan bahwa toksisitas B. thuringiensis H-14 terhadap efektifitas kematian larva Aopheles, untuk setiap konsentrasi. Konsentrasi $0.02 \mathrm{ml}$ dan $0.04 \mathrm{ml}$ efektifitasnya terhadap kematian larva Anopheles hanya sampai hari ke 4 yakni $53.73 \%$ dan 61.68\%. Konsentrasi $0.06 \mathrm{ml}, 0.08 \mathrm{ml}$, dan $0.1 \mathrm{ml}$, efektitasnya terhadap kematian larva Culex sampai hari ke 6, yaitu masing-masing 55.24\%, 56.79\% dan $63.43 \%$.

Gambar 4, menunjukkan toksisitas $B$. thuringiensis sandi isolate 18 terhadap efektivitas kematian larva Culex, dari setiap konsentrasi diperoleh efektifitas setiap konsentrasi $0.02 \mathrm{ml}$ efektif sampai hari ke 2 yaitu $71.57 \%$. Konsentrasi $0.04 \mathrm{ml}$ dan $0.06 \mathrm{ml}$, efektif sampai hari ke 3 yaitu $50.77 \%$, dan $74.50 \%$. Sedangkan konsentrasi 0.08 $\mathrm{ml}$ dan $0.1 \mathrm{ml}$ masing-masing efektif membunuh larva sampai hari ke 4 dan 5 yaitu $60 \%$ dan $53,73 \%$.

Hasil penelitian menunjukkan bahwa isolate lokal B. thuringiensis $\mathrm{H}-14$ dan isolate sandi 18 toksit terhadap larva Anopheles, adapun ciri-ciri larva yang terinfeksi oleh toksin B.thuringiensis tubuhnya mengalami pembengkakan, berwarna biru kecoklatan. Hal yang sama dikemukakan oleh Munif (1997) dan Blondine (1998) bahwa larva yang terinfeksi $B$. thuringienis berhenti makan, tubuhnya mengalami pembengkakan, warna biru kecoklatan. Persentase kematian larva Anopheles dan Culex sangat dipengaruhi oleh jumlah konsentrasi seperti yang ditunjukkan pada grafik 1, 2, 3, dan 4, hal ini sesuai yang dilaporkan oleh Munif (1997) bahwa konsentrasi B.thuringiensis sangat berpengaruh terhadap toksisitas dan lama residunya di dalam air. Hal ini dimungkinkan karena semakin tinggi konsentrasi B.thuringiensis yang diinokulasikan menunjukkan bahwa jumlah sel semakin banyak sehingga peluang untuk termakannya oleh larva semakin besar.

Konsentrasi isolate sandi 18 yang paling efektif membunuh larva Anopheles adalah konsentrasi $0.08 \mathrm{ml}$ dan $0.1 \mathrm{ml}$ efektif sampai hari hari ke 7 , sedangkan konsentrasi yang paling efektif membunuh larva Culex adalah $0.06 \mathrm{ml}, 0.08$ $\mathrm{ml}$, dan $0.1 \mathrm{ml}$ efektif sampai hari ke 5 . Adanya perbedaan persentase waktu efektifitas dapat disebabkan oleh beberapa faktor antara lain daerah makan larva (larval feedeng zone), keberadaan toksin di daerah makan larva, kepekaan masing-masing spesies larva yang diuji, perbedaan serotife bakteri uji, perilaku larva di dalam air, serta pengaruh fisik misalnya $\mathrm{pH}$ dan suhu. Meskipun berdasarkan efektifitas persentase kematian larva berbeda, tetapi berdasarkan hasil analisis statistik dengan uji BNJ dengan taraf kepercayaan 0.05 secara bermakna tidak berbeda antara konsentrasi perlakuan.

\section{KESIMPULAN}

Isolat lokal B. thuringiensis H-14 dan isolate sandi 18 toksit terhadap larva nyamuk Anopheles dan Culex. B.thuringiensis H-14 pada konsentrasi 0.08 dan 0.1 efektif sampai hari 7 terhadap larva Anopheles, sedangkan konsentrasi 0.06, 0.08 dan 0.1 efektif sampai hari ke 6 terhadap Culex. Isolat lokal B.thuringiensis sandi 18 pada konsentrasi 0.08 dan 0.1efektif sampai hari ke 5 terhadap larva Culex, dan konsentrasi 0.1 efektif terhadap Anopheles sampai hari ke 7.

\section{DAFTAR PUSTAKA}

Anonim. 2004a. The Microbial Word. Bacillus thuringiensis File:/ / A $\backslash$ B-t.htm.

Anonim. 2004b. Bacillus thuringiensis Pesticide fact Sheet. Prepared for the U.S. Departement of Agriculture Forest Service by information Venture. Inc. Mail US at: Customer- Service@ @ Information. Com-Http://Info Venture Come-hlth.

Blondine, Ch.P., Widiastuti, dan Widiarti. 1995. Uji Coba Bacillus thuringiensis H-14 Terhadap Jentik Nyamuk Anopheles barbirotris di Laboratorium dan lapangan. Bul.Pen. Kesehat. 23(1): 39-44.

Blondine, Ch.P., Rendro \& Sukarno. 2000. Pengendalian Jentik Nyamuk Vektor Demam Berdarah, Malaria dan Filariasis Menggunakan Strain Lokal Bacillus thuringiensis H-14. Bul.Pen. Kesehat. 27(1): 283-286.

De Bach, P. 1974. Biological Control of Coccids by Introduced Natural Enemis. Plenum, New York. pp: 165- 193.

De Barjac, H. dan J. Bonnefoi. 1968. Essay Classification Biochemical the Bacillus du Type Bacillus thuringiensis Microbial Control of masquito pest and deseases. Acad. Press, London. p. 35-39.

Dubois, N.R. \& F.B. Lewis. 1981. What is Bacillus thuringiensis. Journal. Arboricul. 7(9): 232-240. 
Hadioetomo, R.S., dan I. Rusmana. 1996. Isolasi Bacillus thuringiensis Berl. Dari Peternakan Ulat Sutra dan Toksisitasnya Terhadap Larva Crocidolomia binotalis Zell, dan Spodoptera. Jurnal Hayati. 1(1): 21-23.

Hofte, H. dan R. Whiteley. 1989. Insecticidal Crystal Protein of Bacillus thuringiensis. Microbial. Rev. 53(2):242-255.

Huffakaer, C.B., dan P.S.Messenger. 1989. The Concept and Significance of Natural Control. In. Biological Control of Insect Pest and Weeds.Academic Prees, Toronto, Canada. Pp 12- 28.

Ignofo, C.M. dan C.F. Anderson.1979. Bioinsecticides. Microbial Technology. Academic Prees, New York.

Kasman, S., S. Andrew, dan N. Rabecca. 1998. Display of a Biologically Active Bacillus thuringiensis. Applied and Enviromental Microbiology. 64(8): 2995-3003.

Krieg, A. 1961. The Genus Bacillus Insect Pathogens. The Prokaryotes. Vol. II. Springer-Verlag, Berlin, Heidelberg, New York. 1741-1748

Kurniasari. 1994. Patogenitas Bacillus thuringiensis asal Indonesia terhadap larva Crocidolomia binotalis (Zeil) dan Spodoptera litura. Lap. Pen. IPB- Bogor. hal. 1-6.

Luthy, P. 1980. Insecticydal Toxin of Bacillus thuringiensis. Lett. 8: $1-7$.

Mangoendihardjo. 1989. Teori dan Praktek Pengendalian Biologi. Edisi 1. Penerbit Universitas Indonesia (UIPrees), Jakarta. hal. 13 - 70.

Munif, A. 1997. Pengaruh Bacillus thuringiensis H-14 Formula Tepung Pada Berbagai Instar Larva Nyamuk Aedes aegypti di Laboratorium. Cermin Dunia Kedokteran. (144): $78-91$.

Nadrawati, J.Situmorang, \& Mahrub. 1994. Isolasi Bacillus thuringiensis di Propinsi Daerah Istimewa Yogyakarta dan Uji Patogenitasnya Terhadap Spodoptera litura (Fabricus) dan Plutella xylostella Curt. BPPSUGM.7(1b):3-5.

Norris, P. 1971. The Protein Crystal Toxin of Bacillus thuringiensis. Microbial Control of Insect and Mites. Academic Prees, London, hal 229-246.
Novianti, M. 1999. Pemanfaatan antigen H untuk identifikasi Bacillus thuringiensis. Lap. Pen. IPB,Bogor. hal 1-12.

Oktavina, D.M. 1999. Stabilitas Beberapa Formulasi Bioinsektisida Bacillus thuringiensis Subsp Aizawai. Laporan Penelitian IPB, Bogor. hal 1-6

Permatasari, U. 1998. Kinerja Bacillus thuringiensis dalam Medium Glukosa-Mineral dengan Dua Macam Sumber Nitrogen Yang Berbeda. Laporan Penelitian IPB, Bogor.hal 7-8.

Pramatha, R.B. 1994. Expression of parasporal crystasl protein ( $\delta$-endotoksin) gen $(\delta)$ of Bacillus thuringiensis in sporogenic. J.Biosci.19(2):145-153.

Rukmono. 1991. Perkembangan baru dalam Pemberantasan Malaria. Maj. Kedok. 41: 189-193.

Santosa, dan H. Widyastuti. 1996. Toksisitas Beberapa Isolat Bacillus thuringiensis Terhadap Penggerek Buah Kakao dan karakteristik Gen Cry-nya. Jurnal Menara Perkebunan 64:123-132.

Lantang, 2005. The toxixity of Bacillus thuringiensis Isilates From several soil Habitat On The Some Area In Papua Province At Mosquito Larvae Of Anopheles farauti Laveran And several Its Characteristics. Jurnal Porsimapas. 11: 78 - 99.

Steel, R.G. dan J.H. Torrie. 1991. Prinsip dan Prosedur Statistika. PT. Gramedia Utama, Jakarta.

Subiantoro. 1997. Pertumbuhan Isolat Bacillus thuringiensis Pada Media Air Kelapa dan Uji Patogenitasnya Terhadap Jentik Nyamuk Vektor. Bul. Pen. Kesehat.26(2):95-102.

Wardhani, T. 1996. Bacillus thuringiensis Berliner Alternatif Pestisida Mikroba Untuk Mengendalikan Hama Moruca testulalis Geyer Pada Tanaman Kacang Hijau . Jur. Ilmiah Widya Gama 1(4):101-106.

Widiastuti, Widiarti, dan Sustriayu. 1997. Efikasi Bacillus thuringiensis H-14 (Vectobac G) Terhadap Jentik Nyamuk Anopheles barbirotris di laboratorium. Bul. Pen. Kes. 14(5): 12-19. 